\title{
Impact of Customer Orientation and Quality of Service on Trust and Customer Loyalty
}

\author{
Gst Ayu Oka Windarti ${ }^{1, *}$, Esya Alhadi ${ }^{1}$, Elvia Zahara ${ }^{1}$, Titi Andriani ${ }^{1}$ \\ ${ }^{1}$ Business Administration Department State Polytechnic of Sriwijaya Palembang, Indonesia \\ "Corresponding author. Email: okawidarti@gmail.com
}

\begin{abstract}
Improving the quality of the interrelation among banks and customers can encourage customer loyalty. The study aims to explore the relationship between customer orientation, service quality, customer trust and loyalty. This study used causality research which explained the causal relationship between research variables. The questionnaire was distributed to respondents who were customers in Palembang with a purposive sampling method. Data analysis was carried out by testing the construct validity and reliability. Path analysis using SPSS version 22.00 is used as a data analysis tool. The research findings explain that orientation of customer is significantly and positively related to trust. Quality of service is significantly and positively related to trust. Then, trust is significantly and positively related to loyalty. The results of this study could be a reference for bank managers to remain committed to providing services to customers.
\end{abstract}

Keywords: customer orientation, quality of service, trust, loyalty

\section{INTRODUCTION}

Harmonious relationship between customers and banks will be able to encourage customer loyalty, significantly increase bank profits and increase bank competitiveness in the increasingly fierce competition in the banking business sector [1]. [2] argues that sustainable benefits can only be obtained from customers who have relatively high loyalty. Therefore, maintaining a quality relationship with consumers or customers is an effective strategy for the success of an organization [3], [4]. Nevertheless, the bank's strategy in maintaining quality relationships with customers, anticipating customer needs and creating quality customer relationships is effective in the banking industry competition and bank should provide a quite hard challenge because banking services are intangible [3].

Strategies to improve customer satisfaction and maintain good relations with customers on an ongoing basis, the bank must provide the best service [5]. Research on the relationship between satisfaction, customer trust, and loyalty was conducted by [6] which stated that satisfaction, customer trust is significantly related to loyalty. Research by [7], [8] explained that the image of customers, trust and loyalty of Islamic bank customers is influenced by customer satisfaction. Research that investigates the important dimensions of relationship quality and how it can affect loyalty in retail sectors is still relatively limited [9]. Although the strategy for preserve customers has served an important concern, not entire customers want to be involved in deep contact with service providers [10] since customers differ in connection orientation [11]. In case the bank cannot design a strategy well in building quality relationships with consumers or customers, then their relationship quality program may fail. Also, in the economy of a country, the financial sector plays a very crucial function because they are able to encourage innovation, entrepreneurship and other businesses [12].

\section{LITERATURE REVIEW}

\subsection{Customer Loyalty}

Consumer commitment to buy back consistently selected products/services in the future is called customer loyalty. Banks can get part of the customer's billfold if banks can maintain loyalty. Loyalty has serve a recurring construct in the behavioral study. therefore, it attracts many academic dissemination [13], [14], [15]. Prior research mainly focused on conceptualization of dimensions. Many studies support the classification scheme of attitude and behavior loyalty [16], [17]. [18] state that behavioral loyalty shows the willingness of customers to buy back and connect to the company; attitude loyalty is an emotion and makes customers provide support to the company.

\subsection{Trust}

Trust is an individual's desire to be bound to partners in a relatively long time. The conceptualization of existing beliefs reflects three general features: competence, virtue, and trust. Conceptualization of trust tends to suggest explanation in dimensions but admits that managing every trust element as an independent concept can lead to excess the trust description [19]. Furthermore, [20] stated three of trust components determinate also suitable very well with main aspects of trust: conscious and influence. While 
effective trust involves salespeople capability to create customers perceive safe or insecure hence, making customers dependent or not dependent on salespeople, cognitive trust relates to customer dependence on salespeople because salespeople have the necessary competencies and virtues. Trust help invent sustainable partnership.

\subsection{Customer Orientation}

The fundamental element of market orientation is customer orientation that allocated a synthesizing focus for organizational action and provide a means to implementing marketing concepts. The orientation of customer is not solely a powerful way to business fruitfulness, yet creates the desired proceeds of employees [21]. [22] stated the orientation of customers delineate an employee's resources and the employee's proclivity to comply with client necessity in workplace conditions. Customer orientation as an individual resource can serve as a deterrent to the deleterious effect of job demand, can bring to excellent customer cater delivery, particularly when integrated with organizational endorsement. Employees who provide the best service to customers show excellent attention to the necessity, confidence, and joy of others. Employees also reveal a little tier of anxiety and disillusionment while providing services. Employees who have a perspective on customer orientation will give a smile, serve with polite words and maintain good emotions when interacting with customers [23].

\subsection{Service Quality}

Quality of service from a business or non-business organization to consumers can be seen from the strategy in providing quality assurance of products, service reliability, employee responsiveness, and overall service personalization. The ability and virtue of service providers in serving consumers is one indicator of success in providing quality services. Conversely, in case the corporate presents untrustworthy services and slows down the response to the user, the user cannot create conviction to them. Previous research has revealed the influence quality of service toward customer trust of online vendors [24] and cellular service organization [25]. Quality of service can influence customer experience because trustless connections and slow reactions tend to reduce user pleasure and arrange over the cellular payout system.

\section{METHODS}

\subsection{Measurement of constructs}

Research construct was adapted from various previous studies. Four indicators developed by [26] were employed to quantify customer orientation. Four indicators adapted from [27] were employed to measure service quality. Four indicators developed by [25] were used to measure trust. Then, four indicators developed by [25] were employed to quantify loyalty. All question items will be measured using Likert scale 5 point with criteria strongly agree $=5$ to strongly disagree $=1$.

\subsection{Sample design and data analysis}

Customers of Mandiri bank, BNI, and BCA determine as population. Purposive Sampling was employed to determine bank customers who would become research respondents. The minimum number of samples was required by the analytical tool used. The minimum number of samples was 216 people. The statistical analysis used in this research was path analysis using the SPSS for Windows version 22.00 program.

\section{RESULTS}

\subsection{Validity and Reliability Measurement}

Table 1 presented the results of the validity test for each indicator of the four variables. For customer orientation variables with four indicators, the factor of loading value was greater than 0.60 . So that it could be said that the indicator was valid as a measurement tool for customer orientation variables. Furthermore, the four service quality indicators had values greater than 0.60 which could also be declared valid. Results did not differ greatly for the four indicators of customer trust and customer loyalty with a factor loading value was greater than 0.60 . Table 2 explained that customer orientation, quality of service, trust and loyalty had high reliable values, namely $\alpha$ Cronbach was higher than 0.60. Thus, reliable research instrument can be continued to test further hypotheses.

\subsection{Regression Analysis}

Results of the study explained that trust is influenced by customer orientation positively and significantly. The results of the $t_{\text {value }}$ are 5.481 more than the $t_{\text {statistics }} 2.353$ with sig. 0.000 and $\beta=0.188$. This study supports the research of [19], [28], [29] who describe customer orientation has significant influence trust. If the bank employee and managers have concern in serving its customers and maintaining good relations, it would encourage the customer to trust the bank.

Results of the study explained that trust is influenced by service quality positively and significantly. The results of the $t_{\text {value }}$ are 23.118 more than the $t_{\text {statistics }} 2.353$ with sig. 0.000 and $\beta=0.792$. This study supports the research of [25], [30], [31] who describes service quality has significant influence trust. If bank employees have concern 
in give good services to customers and maintaining good relations, it would encourage the customer to trust the bank.

Results of the study explained that customer loyalty is influenced by trust. The results of the $t$ value are 15.576 more than the $t_{\text {statistics }} 2.353$ with sig. 0.000 and $\beta=0.625$. This study supports the research of [32], [31], [33] who describe trust has significant influence customer loyalty. The level of customer trust with product features, facilities, and services provided by the bank will further encourage the loyalty of bank customers.

Table 1 Results of validity test

\begin{tabular}{|c|c|c|c|}
\hline Variable & Indicator & $\begin{array}{c}\text { Validity } \\
\text { Coefficient }\end{array}$ & Remark \\
\hline Customer Orientation & CO1 & 0.865 & Valid \\
\cline { 2 - 4 } & CO2 & 0.716 & Valid \\
\cline { 2 - 4 } & CO3 & 0.760 & Valid \\
\cline { 2 - 4 } & CO4 & 0.709 & Valid \\
\hline \multirow{7}{*}{ Service Quality } & SQ1 & 0.940 & Valid \\
\cline { 2 - 4 } & SQ2 & 0.944 & Valid \\
\cline { 2 - 4 } & SQ3 & 0.958 & Valid \\
\cline { 2 - 4 } & SQ4 & 0.901 & Valid \\
\hline \multirow{7}{*}{ Trust } & TR1 & 0.927 & Valid \\
\cline { 2 - 4 } & TR2 & 0.961 & Valid \\
\cline { 2 - 4 } & TR3 & 0.936 & Valid \\
\cline { 2 - 4 } & TR4 & 0.946 & Valid \\
\hline \multirow{7}{*}{ Loyalty } & LY1 & 0.942 & Valid \\
\cline { 2 - 4 } & LY2 & 0.951 & Valid \\
\cline { 2 - 4 } & LY3 & 0.981 & Valid \\
\cline { 2 - 4 } & LY4 & 0.963 & Valid \\
\hline
\end{tabular}

Table 2 Results of reliability test

\begin{tabular}{|c|c|c|}
\hline Variable & Reliability coefficient & Remark \\
\hline Customer Orientation & .682 & Reliable \\
\hline Service Quality & .952 & Reliable \\
\hline Trust & .957 & Reliable \\
\hline Loyalty & .971 & Reliable \\
\hline
\end{tabular}

Table 3 Path analysis

\begin{tabular}{|c|c|c|c|c|}
\hline Independent & Dependent & $\mathrm{B}$ & t-value & Sig. \\
\hline Customer orientation & Trust & 0.188 & 5.481 & 0.000 \\
\hline Service quality & Trust & 0.792 & 23.118 & 0.000 \\
\hline Trust & $\begin{array}{c}\text { Customer } \\
\text { loyalty }\end{array}$ & 0.625 & 15.576 & 0.000 \\
\hline \multicolumn{2}{|l|}{ Constanta $=1.663$} & & & \\
\hline \multicolumn{2}{|l|}{ R.S $=.864$} & & & \\
\hline \multicolumn{2}{|l|}{ Adj. R.S $=.862$} & & & \\
\hline \multicolumn{2}{|l|}{ F. statistic $=67.75$} & & & \\
\hline \multicolumn{2}{|l|}{ Significance $=0.000$} & & & \\
\hline
\end{tabular}

\section{CONCLUSION}

The study of bank customer provided empirical proof that supported the linkage among customer orientation, quality of service and loyalty of bank customers. Results of the survey showed that the orientation of customers and improving service quality to customers would have a strong effect on the loyalty of bank customers.
Management of banks must have the capability to identify the element that could be a driver for customers to remain loyal to the bank by developing customer loyalty programs, customer relationship management. Enforcement of a program of customer loyalty was essential to maintain a portfolio availability since the expense of obtaining new client was more expensive.

\section{REFERENCES}

[1] Ndubisi, O.N. (2007). "Relationship quality antecedents: the Malaysian retail banking perspective", International Journal of Quality and Reliability Management, 26(8): pp.829-845

[2] Izogo, E.E. (2016a). "Should relationship quality be measured as a disaggregated or a composite construct?", Management Research Review, 39(1): pp.115-131.

[3] Ndubisi, N.O., Khoo-Lattimore, C., Yang, L., and Capel, C.M. (2011). "The antecedents of relationship quality in Malaysia and New Zealand", International Journal of Quality and Reliability Management, 28(2): pp.233-224.

[4] Izogo, E.E. (2016b). "Structural equation test of relationship quality-repurchase intentionwillingness to recommend framework in retail banking", International Journal of Emerging Markets, 11(3). (Forthcoming).

[5] Caruana, A., and Malta, M. (2002). "Service loyalty: The effects of service quality and the mediating role of customer satisfaction". European Journal of Marketing, 36(7/8): pp.811-828.

[6] Gustafsson, A., Johnson, M.D., and Roos, I. (2005). The effects of customer satisfaction, relationship commitment dimensions and triggers on customer retention. Journal of Marketing, 69: pp.210-218.

[7] Amin, M., Isa, Z., and Fontaine, R. (2013). "Islamic banks: Contrasting the drivers of customer satisfaction on image, trust, and loyalty of Muslim and non-Muslim customers in Malaysia". International Journal of Bank Marketing, 31(2): pp.79-97.

[8] Hoq, M.Z., Sultana, N., and Amin, M. (2010). The effect of trust, customer satisfaction and image on customers' loyalty in the Islamic banking sector. South Asian Journal of Management, 17(1): pp.7093. 
[9] Rafiq, M., Fulford, H., and Lu, X. (2013). "Building customer loyalty in online retailing: the role of relationship quality", Journal of Marketing Management, 29(3/4): pp.494-517.

[10] Shekhar, V., and Gupta, N. (2008). "Customers' perspectives on relationship marketing in the financial service industry", The Italian Journal of Management Research, 7(9): pp.68-79.

[11] De Canniere, M.H., De Pelsmacker, P., and Geuens, M. (2010). "Relationship quality and purchase intention and behavior: the moderating impact of relationship strength", Journal of Business Psychology, 25(1): pp.87-98.

[12] Shin, Y. (2013). "Financial markets: an engine for economic growth", The Regional Economist, 21(3): pp.4-9.

[13] Cater, B., and Cater, T. (2009). "Relationshipvalue-based antecedents of customer satisfaction and loyalty in manufacturing", Journal of Business and Industrial Marketing, 24(8): pp.585-597.

[14] Richard, J.E., and Zhang, A. (2012). Corporate image, loyalty, and commitment in the consumer travel industry, 28(5/6): pp.568-593

[15] Noyan, F., and Şimşek, G.G. (2014). "The antecedents of customer loyalty", Procedia - Social and Behavioural Sciences, 109: pp.1220-1224.

[16] Han, H., and Woods, D.P. (2014). "Attitudinal and behavioural aspects of loyalty in the screen-golf industry", Journal of Quality Assurance in Hospitality and Tourism, 15(2): pp.175-189.

[17] Izogo, E.E. (2015a). "Determinants of attitudinal loyalty in Nigerian telecom service sector: does commitment play a mediating role" Journal of Retailing and Consumer Services, 23: pp.107-117.

[18] Rauyruen, P., and Miller, K.E. (2007). "Relationship quality as a predictor of B2B customer loyalty", Journal of Business Research, 60(1): pp.21-31.

[19] Izogo, E.E., Ogba, I-E. and Nwekpa, K.C. (2016), "Correlates of the determinants of relationship marketing in the retail sector: the Nigerian case", African Journal of Economic and Management Studies, 7(1): pp.30-53.

[20] Sherriff, T.K., Luk, G.A. and Lorna, F. (2013). "Trust in customer-salesperson relationship in
China's retail sector", International Journal of Retail and Distribution Management, 41(3): pp.226-248.

[21] Henning-Thurau, T. (2004). "Customer orientation of service employees: its impact on customer satisfaction, commitment, and retention", International Journal of Service Industry Management, 15(5): pp.460-478.

[22] Brown, T.J., Mowen, J.C., Donavan, T., and Licata, J.W. (2002). "The customer orientation of service workers: personality trait determinants and effects on self- and supervisor performance ratings", Journal of Marketing Research, 39: (2): pp.110-119.

[23] Grandey, A.A. (2003). "When 'the show must go on': surface acting and deep acting as determinants of emotional exhaustion and peer-rated service delivery", Academy of Management Journal, 46(1): pp.86-96.

[24] Gefen, D., and Straub, D.W. (2005). “A practical guide to factorial validity using PLS-Graph: tutorial and annotated example", Communications of the Association for Information Systems, (16): pp.91-109.

[25] Liu, C.T., Guo, Y.M., and Lee, C.H. (2011). "The effects of relationship quality and switching barriers on customer loyalty", International Journal of Information Management, 31(1): pp.7179.

[26] Cheng, J.H., Chen, F.Y., and Chang, Y.H. (2008). "Airline relationship quality: an examination of Taiwanese passengers", Tourism Management, 29(3): pp.487-499.

[27]Zhou, T. (2013). "Understanding continuance usage of mobile sites", Industrial Management and Data Systems, 113(9): pp.1286-1299.

[28] Nakata, C., and Zhu. Z. (2006). Information technology and customer orientation: a study of direct, mediated and interactive linkages. Journal of Marketing Management, 22: pp.319-354.

[29] Doney, P.M., J.M. Barry, and R. Abratt. (2007). "Trust determinants and outcomes in global B2B services". European Journal of Marketing, 41(9/10): pp.1096-1116.

[30] Aliabadi, B. Mi., Shidinavid, B., and Namamian, F. (2013). "Design and Explain the Factors Affecting 
Customer Loyalty in Online Banking", International Research Journal of Applied and Basic Sciences, 4 (9): pp. 2782-2791.

[31] Setiawan, H. (2016). Pengaruh kualitas layanan, persepsi nilai dan kepercayaan terhadap kepuasan dan loyalitas pengguna layanan mobile banking, Jurnal Keuangan dan Perbankan, Vol.20, No.3, hal. 518-528.

[32] Hasan, H., Kiong, T. P., and Ainuddin, R. A (2014). Effects of Perceived Value and Trust on
Customer Loyalty towards Foreign Banks in Sabah, Malaysia, Global Journal of Emerging Trends in e-Business, Marketing and Consumer Psychology, 1 (2): pp.137-153.

[33] Kim, D., and Benbasat, I. (2003). Trust-related arguments in Internet stores: a framework for evaluation, Journal of Electronic Commerce Research, 4 (2): pp.49-64. 